\title{
STUDI KASUS PEMBELAJARAN MIPA BILINGUAL DI TIGA SMA RSBI DI JAWA TENGAH
}

\author{
Gusti Astika dan Anton Wahyana \\ Universitas Kristen Satya Wacana Salatiga \\ e-mail: gustiastika@yahoo.com
}

\begin{abstract}
Abstrak
Penelitian ini bertujuan mendeskripsikan bahasa Inggris yang digunakan oleh guru MIPA di dalam kelas bilingual di SMA RSBI di Jawa Tengah, dari segi perbandingannya dengan penggunaan bahasa Indonesia, kegramatikalannya, dan kompleksitasnya. Penelitian ini menggunakan metode deskriptif dan data penelitian dikumpulkan melalui pengamatan langsung terhadap delapan kelas MIPA dan wawancara dengan guru MIPA dan kepala sekolah. Ujaran guru dan wawancara direkam, ditranskripsikan, dan dianalisis secara kualitatif untuk menjawab pertanyaan penelitian. Temuan penelitian menunjukkan bahwa guru MIPA tidak sepenuhnya menguasai bahasa Inggris untuk kelas bilingual dan ini mempengaruhi sikap siswa terhadap program bilingual. Wawancara dengan guru dan kepala sekolah mengungkap adanya masalah terkait dengan motivasi guru untuk meningkatkan kemampuan berbahasa Inggris meskipun pihak sekolah memberikan dukungan.
\end{abstract}

Kata kunci: bilingual, RSBI, kompleksitas, content-based instruction

\section{A CASE STUDY OF THE BILINGUAL LEARNING OF SCIENCE IN THREE SMA RSBI IN CENTRAL JAVA}

\begin{abstract}
This study aims to describe the English language used by science teachers in SMA RSBI in Central Java in their bilingual classes in terms of its proportion to Indonesian, grammaticalness, and complexity. It used a descriptive method and the data were collected through direct observations of eight science classes and interviews with the science teachers and the school principals. The teacher talk and interview sessions were audio recorded, transcribed, and analysed qualitatively to provide answers to the research questions. The results indicate that the science teachers at the schools did not have sufficient mastery of English for bilingual classes, which affected the students' attitudes to the bilingual program. The interviews with the teachers and school principals also revealed problems with teachers' motivation to improve their English in spite of the supports provided by the school management.
\end{abstract}

Keywords: bilingual, RSBI, complexity, content-based instruction

\section{PENDAHULUAN}

Dalam era globalisasi, bahasa Inggris memegang peranan penting dalam komunikasi internasional baik dalam bidang pembangunan, teknologi, ekonomi, maupun pendidikan. Sejalan dengan arus globalisasi, kebutuhan akan kemampuan berbahasa Inggris semakin terasa. Oleh sebab itu, tidak mengherankan bahwa para ahli yang berkecimpung dalam dunia pendidikan merasa perlu memberikan pelajaran bahasa Inggris secara intensif dan berkesinambungan kepada para anak didik di sekolah menengah, bahkan sejak 
anak-anak masih duduk di bangku sekolah dasar. Pada tingkat sekolah menengah telah banyak sekolah yang sudah menyelenggarakan RintisanSekolah Bertaraf Internasional (RSBI) yang mempersiapkan para siswanya agar pada masa mendatang mereka dapat bersaing dalam era globalisasi. Hal ini dimungkinkan oleh karena adanya mandat dari Undang-Undang Nomor 20 Tahun 2003 tentang Sistem Pendidikan Nasional, Permendiknas Nomor 23 Tahun 2006 tentang Standar Kompetensi Lulusan, dan Peraturan Pemerintah Nomor 19 Tahun 2005 tentang Standar Nasional Pendidikan.

Sejak dikeluarkannya undang-undang dan peraturan tersebut, di Jawa Tengah telah ada sejumlah SMA yang ditetapkan sebagai Rintisan Sekolah Bertaraf Internasional (RSBI) sejak tahun 2006 (Dinas Pendidikan dan Kebudayaan Provinsi Jawa Tengah, Kompas, Mei 2007). Sesuai dengan ketetapan tersebut, salah satu syarat yang harus dipenuhi oleh RSBI ialah memakai bahasa Inggris dalam mengajarkan mata pelajaran Matematika, Kimia, Fisika, Biologi, dan Ekonomi.

Sejak dilaksanakannya program pengajaran MIPA bilingual dengan pengantar bahasa Inggris, banyak persoalan yang muncul antara lain, belum tersedianya buku ajar dalam bahasa Inggris yang cocok dengan kebutuhan sekolah, belum tersedianya silabus dalam bahasa Inggris, belum siapnya guru mengajar dengan pengantar bahasa Inggris, dan belum adanya model pembelajaran MIPA bilingual yang efektif.

Di RSBI, peranan guru-guru tersebut untuk mempersiapkan siswa agar kelak dapat bersaing secara global dalam dunia kerja sangat besar. Keuntungan kompetitif para lulusan sekolah bertaraf internasional antara lain sangat bergantung kepada proses pembelajaran selama pendidikan. Keuntungan kompetitif ini akan dapat dimiliki oleh para siswa jika para guru mempunyai pengetahuan dan keterampilan bahasa Inggris yang memadai baik untuk memahami bahan pelajaran, mengajarkannya, dan melakukan evaluasi.

Tuntutan untuk memakai bahasa Inggris sebagai bahasa pengantar dalam beberapa mata pelajaran tersebut di atas telah mendorong sekolah untuk merancang berbagai program pelatihan bahasa Inggris bagi para guru MIPA.Mereka dikirim ke lembaga-lembaga pendidikan formal untuk mengikuti kursus bahasa Inggris selama beberapa bulan dengan harapan bahwa setelah menyelesaikan kursus mereka akan siap mengajar dalam bahasa Inggris. Ada juga sekolah yang mengundang pakar pendidikan bahasa Inggris untuk memberi pelatihan bahasa Inggris kepada guru-guru MIPA di sekolah secara reguler di tengahtengah kesibukan mereka mengajar.Yang menjadi pertanyaan ialah apakah para guru yang sudah mendapat pelatihan bahasa Inggris sudah siap dengan tugas yang diamanatkan oleh undang undang tersebut di atas. Jika mereka belum siap, pengetahuan atau keterampilan apa yang harus dimiliki oleh para guru agar mereka benar-benar siap mengajar dalam bahasa Inggris. Informasi dari koordinator SMA RSBI se Jawa Tengah menunjukkan bahwa proses belajar-mengajar MIPA bilingual belum bisa berjalan sesuai dengan yang diharapkan walaupun para guru sudah menyelesaikan pelatihan bahasa Inggris (wawancara pribadi). Mereka belum siap dan merasa belum memiliki keterampilan yang memadai untuk melaksanakan pembelajaran bilingual walaupun mereka sudah mengikuti kursus dan pelatihan bahasa Inggris.Hal ini merupakan tantangan yang perlu dicarikan jalan keluarnya melalui sebuah penelitian.

Di RSBI, guru menjadi ujung tombak sistem pembelajaran bilingual dan mempuyai peranan yang sangat strategis dalam mewujudkan cita-cita RSBI. Dengan berkembangnya teknologi informasi dan komunikasi, penguasaan bahasa Inggris baik lisan maupun tulis menjadi syarat utama karena sebagian besar informasi 
dan ilmu pengetahuan dituangkan dan disebarluaskan dalam bahasa Inggris. Sejalan dengan perkembangan RSBI, saat ini sudah ada beberapa buku pelajaran SMA seperti Ekonomi, Geografi, Fisika, Matematika bilingual(bahasa Indonesia dan bahasa Inggris). Perkembangan jumlah buku ajar bilingual akan terus bertambah pada masa yang akan datang dan hal ini menuntut guru mata pelajaran MIPA untuk mengembangkan kemampuan bahasa Inggris jika tidak mau ketinggalan dengan kemajuan dalam bidang pendidikan.

RSBI merupakan perkembangan baru dalam sistem pendidikan nasional Indonesia.Perkembangan ini memerlukan pembaruan daya dukung berupa sarana dan prasarana pendidikan, sistem manajemen sekolah, dan guru yang berkualitas yang dapat menguasai teknologi informasi.Sistem pembelajaran yang konvensional yang bergantung pada papan tulis dan kapur serta dibatasi oleh ruang kelas yang statis tidak dapat lagi sepenuhnya mendukung sistem pembelajaran yang dituntut oleh RSBI. Oleh sebab itu, perlu dirancang model pembelajaran yang dapat mengakomodasi cita-cita SBI dan perkembangan teknologi agar pembelajaran dapat efektif dan kompetitif.

Penelitian awal yang dilakukan oleh Astika, Wahyana dan Andreana (2008) di RSBI Salatiga menunjukkan bahwa semua guru yang menjadi sampel menyatakan bahwa mereka mempunyai pengetahuan yang sangat baik tentang substansi mata pelajaran. Hal ini bisa dimengerti karena mereka mempunyai keahlian dalam mata pelajaran yang selama ini diampu. Dalam hal penguasaan bahasa Inggris, hasil penelitian tersebut menunjukkan kekurangan yang sangat mendasar, yaitu: (a) sebanyak 33,3\% responden menyatakan tidak memiliki bakat berbahasa Inggris, (b) sebanyak 66,7 $\%$ responden tidak dapat mengevaluasi efektifitas materi pelajaran dalam bahasa Inggris namun mereka dapat memahami konsepnya, (c) sebanyak 77,8\% responden tidak dapat menerangkan konsep materi dalam bahasa Inggris, dan (d) semua responden (100 \%) tidak mampu menjelaskan tata bahasa yang ada dalam materi pelajaran. Walupun kemampuan bahasa Inggris guru sangat kurang, mereka (100 $\%)$ mempunyai keinginan untuk selalu mengembangkan pengetahuan bahasa Inggris melalui pelatihan atau kursus. Hal lain yang menggembirakan ialah adanya fasilitas pendukung PBM berupa laboratorium komputer yang terhubung dengan internet yang cukup memadai dan $100 \%$ responden berpendapat bahwa dukungan sekolah untuk melaksanakan program bilingual sebetulnya sudah bagus. Penelitian ini tidak dapat dipakai sebagai ukuran untuk menggambarkan kemampuan bahasa Inggris guru SBI secara umum di Jawa Tengah karena ruang lingkupnya masih terbatas. Namun demikian, hasil penelitian ini dapat dijadikan sebagai langkah awal untuk mengadakan penelitian lanjutan dengan wilayah penelitian yang lebih luas.

Oleh sebab itu, perlu diadakan penelitian untuk mendiskripsikan kemampuan guru MIPA dalam mengajar dengan pengantar bahasa Inggris. Diskripsi kemampuan ini dapat mengungkapkan masalah-masalah kebahasaan (bahasa Inggris) atau kelemahan-kelemahan pedagogik, sehingga dapat dijadikan masukan untuk mencari jalan keluar bagi keberhasilan program RSBI, misalnya dengan mengembangkan model pembelajaran yang sesuai.Berdasarkan uraian di atas, masalah dalam penelitian ini ialah bagaimana kemampuan guru-guru MIPA di SMA RSBI dalam mengajarkan pelajaran MIPA bilingual.

Tujuan penelitian ini ialah untuk mendiskripsikan bahasa Inggris guru yang mencakup tiga hal. Pertama, berapa persen para guru memakai bahasa Inggris di kelas, dan berapa persen mereka memakai bahasa Indonesia. Perbandingan ini memberi gambaran tentang pembelajaran 
dengan dua bahasa (bilingual); bahasa apa yang lebih banyak dipakai oleh guru dalam mengajar. Kedua, tingkat kompleksitas kalimat bahasa Inggris yang dipakai. Kompleksitas struktur kalimat ditentukan dengan menghitung jumlah T-unit dalam kalimat. T-unit ialah gagasan yang ada dalam suatu kalimat. Kalimat sederhana mempunyai satu gagasan atau satu T-unit, sedangkan kalimat kompleks bisa mempunyai dua atau lebih T-unit. Tingkat kompleksitas kalimat menunjukkan kemampuan guru dalam menggunakan bahasa Inggris dalam mengajar. Ketiga, tingkat ketepatan/keakuratan pemakaian tata bahasa. Tingkat keakuratan kalimat ditentukan dari jumlah kalimat yang benar dan salah secara gramatikal dan dihitung persentasenya.

Penelitian ini didasarkan pada teori pendekatan content-based instruction (Brinton \& Wesche, 1989) dengan asumsi bahwa para guru mempunyai pengetahuan yang cukup tentang mata pelajaran yang akan diajarkan (content knowledge). Yang menjadi pertanyaan apakah pengetahuan dan keterampilanpara guru tersebut untuk memakai bahasa Inggris dalam mengajarkan content knowledge sudah memadai seperti yang diharapkan.

Salah satu bentuk pembelajaran dalam pendekatan yang berdasarkan pada content (isi) ialah program pengajaran English for Specific Purposes yang disingkat ESP (Dudley-Evans \& St John, 1998). Dalam konteks RSBI, mengajar dengan medium bahasa Inggris merupakan salah satu bentuk program ESP (Hutchinson \& Waters, 2006). Bentuk lain dari pengajaran berbasis isi ialah program imersi di mana proses belajar- mengajar sepenuhnya menggunakan bahasa Inggris. Keunggulan program ESP ialah materi pelajaran ditulis dalam bahasa Inggris dan relevan dengan program akademik siswa.Dengan demikian, proses belajar menjadi sangat bermakna dan dapat menjadi faktor pendorong motivasi belajar.
Guru MIPA bilingual di SMA RSBI mempunyai tiga macam peran dalam menjalankan tugasnya: (i) sebagai praktisi, (ii) sebagai perancang materi, dan (iii) sebagai evaluator. Sebagai praktisi, guru mempunyai tugas untuk merancang dan mengatur proses belajar-mengajar, memberi penjelasan masalah-masalah kebahasaan (bahasa Inggris), dan secara terus menerus mengembangkan kemampuan berbahasa Inggris. Dalam perannya sebagai perancang materi, guru mempunyai tugas untuk merencanakan PBM, memilih materi yang cocok dengan silabus, memodifikasi materi supaya sesuai dengan tingkat kemampuan siswa, atau membuat materi yang baru sama sekali jika materi yang siap pakai tidak ada. Sebagai evaluator, guru mempunyai tugas untuk mengevaluasi efektivitas materi pelajaran dan melakukan evaluasi terhadap pemerolehan belajar siswa. Ketiga peran tersebut di atas dapat dijalankan dengan baik jika bahasa Inggris merupakan bahasa pertama atau bahasa kedua, dan guru tidak mengalami kesulitan dalam menggunakan bahasa Inggris karena mereka adalah penutur asli bahasa Inggris. Dalam konteks pendidikan di Indonesia, bahasa Inggris adalah bahasa asing yang harus dipelajari dan diajarkan dengan model pendekatan yang berbeda dengan model pendekatan pembelajaran di negara-negara yang berbahasa Inggris di mana para guru tidak mempunyai masalah dengan bahasa pengantar. Masalah yang dihadapi oleh para guru MIPA di SMA RSBI ialah pengetahuan dan keterampilan menggunakan bahasa Inggris.

Dalam menjalankan proses belajarmengajar, para guru MIPA di SMA SBI harus mempunyai dua macam pengetahuan kebahasaan, yaitu pengetahuan tentang kosakata/istilah tehnis (technical vocabulary) dalam bidang tertentu dan pengetahuan tentang tata bahasa Inggris. Menerangkan konsep yang terkandung dalam istilah-istilah teknis mungkin 
bukan merupakan masalah yang terlalu berat karena guru sudah mempunyai latar belakang ilmu yang diajarkan. Ini merupakan kekuatan bagi guru MIPA. Yang perlu harus dikembangkan ialah pengetahuan tentang tata bahasa dan keterampilan menggunakan bahasa Inggris baik untuk keperluan umum (non-pedagogik) maupun untuk mengajarkan materi pelajaran (keterampilan pedagogik). Bagaimanapun juga, mengajarkan MIPA dengan pengantar bahasa Inggris tidak bisa lepas dari pengajaran tata bahasa walaupun cara mangajarkannya tidak persis sama seperti mengajarkan tata bahasa dalam pelajaran bahasa Inggris sebagai mata pelajaran wajib (English for General Purposes) pada umumnya.

Dalam mengajar, guru MIPA akan selalu mengadakan interaksi verbal dengan siswa baik satu arah maupun dua arah. Dalam hubungan ini, ada berbagai fungsi bahasa yang perlu dikuasai oleh guru MIPA dalam mengajarkan materi (content knowledge), misalnya saja: menjelaskan konsep, melaporkan kejadian tertentu, memberikan definisi, memberi instruksi, menjelaskan proses, menjelaskan klasifikasi, memberi contoh, menerangkan tabel, gambar, ilustrasi, atau grafik, membandingkan dua masalah, membuat kesimpulan, dll.(Gillet, 2007). Fungsi-fungsi bahasa seperti ini memerlukan transactional skills, yaitu keterampilan untuk menyampaikan informasi yang bersifat satu arah,dan interactional skills, yaitu keterampilan untuk melakukan interaksi bahasa dua arah, misalnya dalam diskusi walaupun dalam bentuk sederhana, atau dalam menjawab pertanyaan atau memberikan feedback (Yule, 1997). Dalam proses pembelajaran bahasa, dikenal dua macam feedback, yaitu feedback terhadap kesalahan tata bahasa (Doughty \& Williams, 1998) dan feedback terhadap masalah makna komunikasi seperti yang terungkap dalam penelitian Astika (2007). Kedua macam feedback tersebut bisa juga dilakukan da- lam bentuk tulis jika penilaian terhadap hasil pembelajaran siswa dilakukan dalam bentuk tertulis, atau dalam bentuk dialog (Weisberg, 2006), di mana guru selama proses belajar berlangsung, berdialog dengan siswa dengan tujuan agar siswa dapat menyelesaikan tugas. Oleh sebab itulah, guru harus memiliki keterampilan bahasa Inggris tingkat lanjut.

\section{METODE}

Metode yang dipakai dalam penelitian ini ialah deskriptif (Seliger \& Shohamy, 1989) untuk menggambarkan keterampilan guru MIPA dalam mengajarkan pelajaran MIPA bilingual. Penelitian ini menggunakan 3 sekolah sampel di Jawa Tengah yang dipilih secara purposive dengan pertimbangan bahwa sekolah tersebut merupakan sekolah favorit yang sudah memperoleh status RSBI. Langkah pertama yang dilakukan ialah observasi kelas secara langsung (Nunan, 1995) dalam pelajaran MIPA. Bahasa guru, baik bahasa Indonesia maupun bahasa Inggris direkam dengan menggunakan tape recorder. Sesudah observasi kelas, diadakan wawancara mendalam (Rice \& Ezzy, 1999) secara terpisah dengan guru yang diobservasi dan kepala sekolah. Wawancara dengan guru difokuskan pada masalahmasalah kebahasaan bahasa Inggris dan masalah pedagogik dalam mengajar. Sedangkan wawancara dengan kepala sekolah difokuskan pada masalah administratif dan manajerial kelas bilingual. Hasil observasi kelas berupa data kualitatif, yaitu transkrip rekaman bahasa guru. Data ini dianalisis untuk menemukan perbandingan penggunaan bahasa Inggris dan bahasa Indonesia, tingkat kompleksitas bahasa Inggris guru, dan tingkat keakuratan tata bahasa. Langkah selanjutnya ialah membuat model pembelajaran MIPA bilingual dengan memperhatikan hasil observasi kelas dan wawancara dengan guru dan kepala sekolah. 
Tabel 1. Hasil observasi kelas

\begin{tabular}{|c|c|c|c|c|c|c|}
\hline \multicolumn{1}{|c|}{$\mathbf{1}$} & $\mathbf{2}$ & $\mathbf{3}$ & $\mathbf{5}$ & $\mathbf{6}$ & $\mathbf{7}$ \\
\hline JUMLAH & INGGRIS & INDONESIA & GRAMATIKAL & $\begin{array}{c}\text { TDK. } \\
\text { GRAMATIKAL }\end{array}$ & KALIMAT & T-UNIT \\
\hline Kimia (1) & 144 & 47 & 67 & 77 & 128 & 132 \\
\hline Kimia (2) & 9 & 154 & 4 & 5 & 11 & 11 \\
\hline Biologi (1) & 93 & 3 & 38 & 55 & 93 & 96 \\
\hline Biologi (2) & 72 & 19 & 43 & 29 & 67 & 69 \\
\hline Fisika (1) & 141 & 9 & 56 & 83 & 129 & 137 \\
\hline Fisika (2) & 119 & 104 & 48 & 66 & 115 & 116 \\
\hline Matematika & 198 & 65 & 96 & 104 & 192 & 199 \\
\hline Ekonomi & 207 & 2 & 59 & 107 & 165 & 166 \\
\hline TOTAL & 983 & 403 & 411 & 526 & 900 & 926 \\
\hline \% & 0.71 & 0.29 & 0.44 & 0.56 & T-UNIT & 1.03 \\
\hline
\end{tabular}

\section{HASIL DAN PEMBAHASAN}

Bagian ini menyajikan temuan-temuan penelitian dari tiga sekolah sampel di Jawa Tengah yang berhasil dihubungi untuk dijadikan sampel penelitian. Kelas yang diobservasi ialah kelas mata pelajaran Kimia (2 kelas), Biologi (2 kelas), Fisika (2 kelas), Matematika (1 kelas), dan Ekonomi (1 kelas).Temuan-temuan penelitian disajikan dalam 3 bagian; yaitu temuan observasi kelas, wawancara dengan guru dan kepala sekolah, dan catatan lapangan.

\section{Observasi kelas}

Observasi kelas bertujuan untuk menemukan (a) perbandingan pemakaian bahasa Inggris dan bahasa Indonesia yang dihitung dalam persen, rata-rata per jam pelajaran, (b) kompleksitas bahasa Inggris guru, yang dihitung dari rata-rata jumlah T-unit dalam kalimat, dan (c) keakuratan tata bahasa guru (grammaticalness), yang dihitung dalam persen kalimat yang benar dan salah ditinjau dari segi tata bahasa. Di bawah ini disajikan temuan dari observasi kelas yang mencakup ketiga aspek kebahasaan tersebut di atas.
Kolom 2 dan 3 menunjukkan jumlah pemakaian bahasa Indonesia dan bahasa Inggris. Kolom 4 dan 5 menunjukkan jumlah kalimat benar dan kalimat yang salah dari segi tata bahasa, kolom 6 menunjukkan jumlah kalimat yang dipakai dalam mata pelajaran, dan kolom 7 menunjukkan T-unit dalam kalimat yang dipakai.

Dari tabel di atas dapat dilihat bahwa guru memakai bahasa Inggris lebih banyak daripada bahasa Indonesia; 71\% bahasa Inggris dan 29\% bahasa Indonesia. Ditinjau dari keakuratan tata bahasa, lebih banyak kalimat yang salah dari pada kalimat yang benar; $56 \%$ salah dan $44 \%$ benar. Rata-rata T-unit dalam seluruh kalimat ialah sebesar 1.03, angka yang sangat rendah, mendekati angka 1.

Temuan-temuan ini menunjukkan bahwa para guru berusaha mamakai bahasa Inggris sebanyak-banyaknya $(71 \%)$ selama pelajaran berlangsung (baca: selama diobservasi) dan menghindari memakai bahasa Indonesia sedapat mungkin (29\%). Temuan ini cukup menggembirakan kalau hanya dilihat dari perbandingan persentase pemakaian bahasaIndonesia dan bahasa Inggris. 
Namun demikian, temuan ini tidak bisa dibanggakan karena dalam wawancara dengan salah seorang wakil kepala sekolah terungkap bahwa guru-guru yang bersedia diobservasi untuk tujuan penelitian ialah hanya mereka yang merasa siap dan merasa bahasa Inggrisnya cukup bagus. Jadi mereka mempunyai kepercayaan diri yang cukup untuk mengajar dengan pengantar bahasa Inggris. Sebagian besar guru di sekolah tersebut merasa belum mempunyai kemampuan yang memadai untuk mengajar dengan pengantar bahasa Inggris. Hasil temuan ini mungkin saja akan berbeda jika observasi kelas dilakukan secara mendadak; tidak diberitahukan terlebih dahulu, atau dilakukan tanpa sepengetahuan guru. Jika hal ini dilakukan sudah tentu akan melanggar kode etik penelitian khususnya jika penelitian menyangkut manusia sebagai subjek.

Temuan kedua (poin b) di atas memberikan bukti yang lebih jelas bahwa sebenarnya kualitas bahasa guru masih jauh dari kriteria baik dan benar, yang ditunjukkan oleh perbandingan antara kalimat yang benar (44\%) dan kalimat yang tidak benar (56\%) secara gramatikal. Ini berarti bahwa selama mengajar, lebih dari setengah jumlah kalimat yang dipakai guru tidak benar dengan berbagai jenis kesalahan, baik dari segi ucapan, pemilihan kata, susunan kalimat, maupun jenis-jenis fungsi bahasa dalam pengajaran. Bahasa yang tidak benar akan sulit dimengerti/ dipahami dan tidak bisa mengkomunikasikan pesan dengan baik. Dalam konteks pembelajaran di kelas, bahasa guru yang sukar dipahami dapat berdampak negatif pada pemahaman dan daya serap siswa.Jika hal ini terus berlangsung, sangat sulit kiranya untuk mengharapkan siswa mempunyai ilmu yang bisa dibanggakan dan mempunyai daya saing nasional apalagi internasional. Dengan kondisi seperti ini cita-cita SBI tidak akan pernah terwujud.

Mutu bahasa Inggris guru juga dapat dilihat dari tingkat kompleksitas kalimat yang ditunjukkan oleh jumlah rata-rata T-unit dalam kalimat.Secara sederhana bisa dikatakan bahwa kalimat yang terdiri dari satu T-unit termasuk kalimat yang sederhana, sedangkan kalimat yang terdiri dari lebih dari satu T-unit temasuk kalimat majemuk (kompleks).Semakin besar jumlah T-unit, semakin kompleks ide atau gagasan yang terkandung dalam kalimat. Kalimat yang kompleks ditandai antara lain oleh pemakaian kata sambung yang menghubungkan dua gagasan atau lebih. Gagasan dalam kalimat bisa menunjukkan hubungan sebab akibat, hubungan kesetaraan, gagasan yang berlawanan, klasifikasi, contoh, argumentasi, kesimpulan, perbandingan, dll. Dalam menjelaskan pelajaran, guru harus bisa mengungkapkan jenis-jenis gagasan seperti ini melalui kalimat-kalimat yang kompleks. Temuan dalam penelitian ini menunjukkan bahwa tingkat kompleksitas kalimat guru masih sangat rendah, yaitu 1.03. Dengan kata lain, kalimat guru sangat sederhana. Kalimat seperti ini tidak efektif untuk menyampaikan konsepkonsep dalam pelajaran MIPA yang pada umumnya harus disampaikan melalui kalimat kompleks.

Dari perspektif pemerolehan dan pembelajaran bahasa, ada tiga ciri yang menunjukkan penguasaan bahasa, yaitu ketepatan/keakuratan berbahasa (accuracy), kelancaran berbahasa (fluency), dan kompleksitas gagasan yang ingin disampaikan (complexity).Bahasa guru dalam penelitian ini tidak menunjukkan penguasaan bahasa Inggris yang seharusnya dipakai dalam pembelajaran MIPA. Bahasa guru menunjukkan ciri-ciri bahasa anak yang sedang belajar bahasa kedua, kalimatnya pendek pendek, terputus putus dan banyak dalam bentuk frase saja, dan bukan kalimat lengkap.

Bahasa yang dipakai dalam mengajar termasuk bahasa akademik yang dapat dianalisis dari segi fungsi retorika bahasa lisan (http://www.uefap.com/speaking). Dalam Tabel 1 dapat dilihat bahwa 56\% 
kalimat guru salah. Berdasarkan kategori di atas, kesalahan bahasa guru dapat dikelompokkan dalam 5 bagian, yaitu kesalahan menggunakan kalimat tanya (asking questions), kesalahan dalam mengungkapkan klasifikasi (classifying objects), kesalahan dalam mendeskripsikan sesuatu (describing objects), kesalahan dalam menjelaskan (expressing explanation), dan kesalahan dalam memberikan instruksi (giving insructions). Dalam proses belajarmengajar, kesalahan menggunakan fungsi-fungsi bahasa tersebut merupakan kesalahan yang serius baik dari segi komunikasi bahasa untuk menyampaikan konsep-konsep penting dalam pokok bahasan, maupun dari segi pemerolehan bahasa siswa yaitu pembelajaran bahasa Inggris. Dengan kualitas bahasa guru seperti ini siswa tidak akan dapat menguasai substansi pelajaran sebagaimana mestinya.

\section{Temuan lain dalam observasi kelas}

Di samping rekaman pelajaran, ada beberapa temuan lain dari catatan lapangan (fieldnotes) yang menarik untuk dilaporkan.

1. Pemanfaatan alat bantu mengajar Sebagian besar guru memakai laptop dan menayangkan bahan pelajaran dengan bantuan LCD. Sayangnya, LCD tidak dipakai secara maksimal; guru hanya menayangkan slide pertama sejak awal pelajaran sampai bel berbunyi. Inipun tidak disertai dengan pembahasan secara tuntas tentang bahan pelajaran yang ditayangkan. Tayangan pelajaran yang hanya 1 slide itu seolah-olah menjadi ciri bahwa proses belajar-mengajar telah memanfaatkan fasilitas teknologi. Pemanfaatan teknologi seperti ini terjadi pada tiga kelas yang diobservasi.

2. Guru menghindari memakai bahasa Inggris

Ada guru yang mengerjakan pekerjaan lain pada saat siswa mengerjakan tugas yang diberikan di kelas. Akibat- nya, banyak waktu yang terbuang, tidak banyak bahasa Inggris yang da-pat direkam karena guru hanya duduk di kursi guru - dia tidak berbicara. Hal yang sama juga terjadi pada saat guru berkeliling membantu siswa memecahkan soal yang diberikan. Bahasa guru tidak dapat direkam walaupun alat perekam dimasukkan ke dalam saku baju. Guru tidak banyak memberi penjelasan secara verbal.Guru menulis beberapa catatan di buku siswa tanpa banyak berbicara. Rupa-rupanya guru menghindari memakai bahasa Inggris dengan cara menyibukkan diri yang tidak memerlukan pemakaian bahasa Inggris.

3. Interaksi guru-siswa

Pada semua kelas yang diobservasi, tidak terjadi interaksi yang efektif antara guru dan siswa di mana mereka terlibat dalam pemakaian bahasa Inggris. Komunikasi berjalan satu arah, hanya dari guru dengan kualitas bahasa seperti yang diuraikan di atas. Peran siswa hanya sebagai pendengar, tidak terjadi diskusi atau tanya-jawab yang produktif untuk membahas pokok bahasan. Interaksi yang terjadi hanya pada saat guru memberi salam, 'Good morning!', 'How are you today?' atau pada saat guru memakai bahasa Inggris pada tataran 'classroom language'. Tidak ada interaksi pada saat guru membicarakan substansi pelajaran. Ini merupakan bukti lain dari keterampilan bahasa Inggris guru yang belum memadai untuk melaksanakan PBM bilingual secara interaktif.

4. Pelafalan bahasa Inggris

Pelafalan (pronunciation) bahasa Inggris guru menjadi masalah lain dalam mengajar. Walaupun pelafalan guru tidak bisa diharapkan seperti pelafalan penutur asli, tidak berlebihan jika kita mengharapkan para guru dapat mengucapkan kata-kata dengan benar sehingga tidak menimbulkan 
salah paham. Guru harus menjadi model yang benar bagi siswa, terlebih lagi jika mengingat status bahasa Inggris di Indonesia sebagai bahasa asing. Paparan (exposure) bahasa Inggris yang bersifat mendidik sebagian besar terjadi di sekolah. Jika guru tidak bisa menjadi model yang bagus, kita tidak bisa mengharap siswa dapat memakai bahasa Inggris dengan benar.

5. Tulisan bahasa Inggris guru di papan tulis

Tulisan bahasa Indonesia berbeda dengan tulisan bahasa Inggris dalam hal ejaan. Tulisan bahasa Inggris guru perlu mendapat perhatian yang sungguh-sungguh karena siswa selalu akan menyalin tulisan guru. Tulisan bahasa Inggris harus jelas dan mudah dibaca, perbedaan antara huruf [a] dan $[\mathrm{u}]$, perbedaan antara huruf $[\mathrm{e}]$ dan [i], perbedaan antara huruf [n] dan [u], dan lain sebagainya harus jelas. Dalam beberapa pelajaran, tulisan guru di papan tulis tidak bisa dibaca dengan jelas.

\section{Temuan wawancara}

Wawancara dilakukan dengan kepala sekolah dan guru setelah mereka mengajar. Tujuannya ialah untuk mengidentifikasi masalah yang muncul dalam pelaksanaan RSBI baik dari perspektif manajerial maupun proses pembelajaran MIPA bilingual.

\section{Temuan wawancara dengan guru}

Dari perspektif proses belajar-mengajar, pelaksanaan pelajaran MIPA bilingual menimbulkan berbagai masalah karena pelaksanaannya bergeser dari aras kelas ke aras sekolah. Pada awalnya, hanya ada satu kelas bilingual dan gurunya dipilih berdasarkan kemampuan akademik dan motivasi yang kuat. Kemudian muncul kebijakan untuk mengangkat program ini ke aras sekolah yang berarti bahwa semua pembelajaran kelas MIPA harus dilaksanakan secara bilingual dan perubahan ini menimbulkan implikasi yang tidak sederhana. Semua guru MIPA harus melaksanakan pembelajaran bilingual tanpa mempertimbangkan kemampuan bahasa Inggirs atau motivasi untuk mendukung keberhasilan RSBI. Tidak semua guru mau melaksanakan tanggung jawab dengan sungguh-sungguh dan sikap ini mempunyai dampak negatif terhadap guru yang melaksanakan tanggung jawab dengan sungguh-sungguh. Akhirnya muncul kecenderungan sementara guru untuk ikut-ikutan saja, sekedar melaksanakan tanggung jawab karena tidak ada bedanya antara guru yang betul-betul bertanggung jawab dengan guru yang sekedar melaksanakan tugas.Pembelajaran kelas bilingual dianggap sebagai beban.

Untuk mengatasi masalah kelemahan guru dalam bidang bahasa Inggris, pihak sekolah merancang program pelatihan dengan berbagai cara, antara lain mengirim guru ke lembaga kursus bahasa Inggris, bekerjasama dengan lembaga pendidikan bahasa Inggris, atau menyelenggarakan in-house training dengan memanfaatkan guru bahasa Inggris di sekolah. Dari wawancara dengan para guru terungkap beberapa masalah dalam pelaksanaan program-program pelatihan. Pertama, kursus bahasa Inggris yang diselenggarakan tidak intensif, berlangsung hanya beberapa minggu, tidak ada kesinambungan, sehingga apa yang sudah dilatihkan tidak bisa bertahan lama. Akibatnya, guru lupa. Kedua, program pelatihan bersifat umum, tidak memberikan apa yang dibutuhkan guru untuk kelas bilingual. Kursus dengan bahan pelatihan yang bersifat umum memang dapat membantu guru untuk mengekspresikan diri secara sederhana dalam komunikasi sehari-hari.Yang lebih penting, menurut guru, ialah bagaimana mereka bisa dibina untuk dapat membentuk kebiasaan dalam menyampaikan bahan pelajaran di kelas.

Kondisi ini memang dilematis. Di satu pihak, guru dituntut untuk dapat mandiri 
mengajar dalam bahasa Inggris sesudah selesai program pelatihan.Untuk dapat mengajar dengan baik dalam bahasa Inggris diperlukan keterampilan tingkat lanjut. Keterampilan ini tidak dapat dikuasai dalam waktu singkat, perlu pelatihan yang lama secara berkesinambungan dengan program yang dirancang dengan ketat dan cermat. Di pihak lain, penyelenggara pelatihan harus memberikan pelatihan yang sesuai dengan tingkat kemampuan guru yang notabene masih pada tingkat dasar. Untuk sampai pada tingkat lanjut diperlukan waktu yang lama dan program yang berkelanjutan. Dari perspektif pemerolehan bahasa asing, belajar bahasa pada usia di atas 40 tahun, apalagi sudah mempunyai pekerjaan tetap, mempunyai banyak kendala, antara lain motivasi belajar, bakat bahasa (language aptitude), waktu, dll. In-house training dengan memanfaatkan guruguru bahasa Inggris di sekolah, menurut salah seorang guru MIPA, mempunyai hambatan psiko-logis karena ada kecenderungan menggurui teman sendiri, merasa dibutuhkan, merasa lebih pandai, dll. Pada awalnya, in-house training dapat berjalan lancar. Lama kelamaan, program seperti ini kehilangan daya tariknya dan kehadiran guru makin menurun karena berbagai alasan.

Para guru MIPA tidak mempunyai masalah dengan substansi bahan pelajaran karena itu merupakan bidang mereka. Yang menjadi masalah ialah bagaimana menyampaikan bahan pelajaran dengan menggunakan bahasa Inggris. Mereka juga mengungkapkan kekhawatirannya tentang pemahaman siswa akibat kelemahan guru dalam menyampaikan bahan. Ini dirasakan sebagai beban apalagi jika materi pelajarannya sulit, guru merasa tidak mampu mengajarkan materi. Ketidakmampuan ini sering menyebabkan mereka enggan untuk terus mengembangkan keterampilan bahasa Inggris. Perasaan putus asa ini mungkin saja disebabkan oleh materi pelatihan yang tidak sesuai dengan kebutuhan guru. Salah seorang guru mengatakan bahwa dia menganggap bahan tata bahasa yang diberikan dalam pelatihan terlalu muluk-muluk. Mereka ingin materi tata bahasa yang sederhana saja. Di samping itu, mereka juga merasa kurang mendapat latihan pelafalan (pronunciation). Komentar guru tersebut ada benarnya karena dalam observasi kelas, sering sekali guru salah melafalkan kata bahkan kata yang sangat sederhana sekalipun.

Tuntutan memakai bahasa Inggris di kelas MIPA menempatkan guru pada situasi yang dilematis. Jika guru selalu memakai bahasa Inggris, besar kemungkinan siswa tidak dapat menguasai konsep materi dengan benar karena penguasaan bahasa Inggris merekapun belum cukup memadai untuk menguasai konsep materi yang disampaikan dalam bahasa Inggris. Jika guru memakai bahasa Inggris dan bahasa Indonesia secara bergantian, guru akan kehilangan waktu karena harus mengulang penjelasan materi dalam bahasa Indonesia. Akibat lanjutannya ialah materi pelajaran tidak bisa diselesaikan pada waktunya. Seorang guru Kimia mengatakan bahwa siswanya tidak dapat mengerti materi dengan jelas karena kemampuan guru itu sendiri dalam menyampaikan materi dalam bahasa Inggris dan kemampuan bahasa Inggris siswa yang juga tidak baik. Banyak siswa yang minta agar pelajaran diulang dalam bahasa Indonesia khususnya jika sudah mendekati ujian nasional. Dalam hal evaluasi, siswa lebih suka kalau soal-soal tes ditulis dalam bahasa Indonesia. Jika bahasa Inggris yang dipakai, siswa minta agar soal tes diterjemahkan dulu ke dalam bahasa Indonesia. Ini berarti guru bekerja dua kali: membuat tes dalam bahasa Inggris, kemudian pada waktu tes diselenggarakan, guru harus menerjemahkannya terlebih dahulu. Ini menunjukkan bahwa siswa memiliki kemampuan bahasa Inggris yang rendah untuk memahami materi. Para siswa di kelas MIPA bilingual 
memiliki kepercayaan diri yang rendah jika diberi tugas atau pekerjaan rumah dalam bahasa Inggris. Para siswa menyatakan bahwa mereka menganggap pelajaran MIPA semakin sukar karena disampaikan dalam bahasa Inggris.

Permintaan siswa agar materi pelajaran dan soal-soal tes diulang dalam bahasa Indonesia patut kita perhatikan karena ada masalah yang penting di balik permintaan tersebut. Wawancara dengan seorang kepala sekolah mengungkapkan bahwa dalam percakapan informal dengan siswa, justru siswa yang pandai lebih senang jika pelajaran disampaikan dalam bahasa Indonesia. Alasannya ialah mereka tidak mau kehilangan waktu karena harus mempelajari bahan dalam bahasa Inggris. Dengan bahasa Indonesia, mereka dapat belajar lebih banyak, mereka bisa mengatur waktu, dan tidak terkendala oleh bahasa Inggris. Informasi ini sangat menarik. Jika anak yang pandai lebih suka pelajaran dengan bahasa Indonesia, bisa ditebak bahwa siswa yang kurang pandai dan siswa yang lemah pasti akan memilih bahasa Indonesia juga. Seorang guru mengungkapkan bahwa ketika siswa memakai buku bilingual, mereka lebih sering membaca teks bahasa Indonesianya, bahkan banyak siswa yang tidak memperhatikan teks bahasa Inggrisnya. Hal ini juga menjadi salah satu penyebab mengapa guru lebih suka memakai buku versi bahasa Indonesia walaupun sebenarnya mereka juga mempunyai buku versi bahasa Inggris.

Mengingat kondisi sekolah dan mutu sumber daya guru, ada sementara guru MIPA yang mengambil jalan tengah, yaitu menerangkan materi dalam bahasa Inggris dengan memakai alat bantu LCD dan di sela-selanya diselipkan bahasa Indonesia untuk menjelaskan hal hal yang penting saja supaya siswa tidak salah konsep. Temuan wawancara dengan guru MIPA di atas menunjukkan bahwa sebenarnya pembelajaran MIPA bilingual di RSBI belum dapat dikatakan berjalan dengan baik karena faktor guru dan siswa.

\section{Temuan wawancara dengan kepala sekolah}

Pembelajaran MIPA bilingual di RSBI memerlukan sumber daya guru yang siap mengajar, artinya guru mempunyai kemampuan yang diperlukan untuk mengajar MIPA dalam bahasa Inggris. Menurut salah seorang kepala sekolah, kenyataan menunjukkan bahwa sebenarnya pembelajaran MIPA bilingual belum seperti yang diharapkan dalam pertemuan-pertemuan formal di forumforum resmi RSBI, artinya belum sesuai dengan keinginan pembuat kebijakan RSBI. Implementasi pembelajaran MIPA bilingual pada umumnya masih pada aras classroom language, yaitu bahasa Inggris yang dipakai untuk komunikasi kelas di luar substansi materi pelajaran, misalnya menyapa, memberi perintah untuk membuka buku, membaca halaman tertentu, atau basa-basi lain. Pembelajaran konsep yang sesungguhnya belum sepenuhnya bisa dilaksanakan karena berbagai kendala seperti yang dibahas di atas.

Kendala lain pelaksanaan MIPA bilingual ialah belum adanya buku baku yang dipakai di RSBI seluruh Indonesia. Buku-buku dari luar negeri misalnya dari Cambridge tidak bisa dipakai begitu saja secara utuh karena ada materi yang perlu diadaptasi atau dipotong karena tidak sesuai dengan kebutuhan siswa Indonesia.Jika buku ditulis sendiri, kendalanya ialah bahasa Inggris. Buku-buku bilingual yang beredar saat ini mempunyai banyak kekurangan, antara lain belum mengakomodasi standar kompetensi lulusan seperti yang dituntut oleh KTSP.

Proses belajar- mengajar di RSBI tidak bisa lepas dari pemakaian alat bantu mengajar (AVA) seperti komputer atau LCD. Informasi dari wawancara dengan kepala sekolah menunjukkan bahwa sekolahsekolah RSBI mempunyai fasilitas yang cukup memadai untuk melaksanakan praktikum di laboratorium sain atau lab 
komputer dengan perangkat lunak yang dibutuhkan. Fasilitas hot spot atau wi-fi juga sudah dipasang di sekolah-sekolah. Yang menjadi masalah bagi sebagian kepala sekolah sebagai manajer ialah bagaimana membangun mindsetatau pola pikir para guru agar mau secara terus menerus mengembangkan kemampuan dan wawasan profesionalnya menuju pendidikan berwawasan internasional.

Usaha kepala sekolah untuk membangun RSBI dengan nuansa internasional telah pula dicoba dengan mengirim guru-guru ke lembaga pendidikan bahasa Inggris dengan harapan bahwa akan terbentuk komunitas akademik yang mempunyai karakteristik internasional. Di samping itu, telah dicoba pula membentuk kelompok-kelompok guru yang dimentori oleh guru bahasa Inggris. Pada awalnya program seperti ini berjalan dengan lancar, tetapi tidak dapat bertahan lama karena kehadiran guru tidak bisa dipertahankan karena berbagai alasan seperti tuntutan mengajar 24 jam seminggu dan adanya kelas sore. Dengan kata lain, dukungan pihak sekolah tidak dimanfaatkan secara optimal oleh para guru MIPA.

Hal lain yang perlu mendapat perhatian berdasarkan wawancara dengan kepala sekolah ialah tanggapan para siswa terhadap pembelajaran MIPA bilingual. Para kepala sekolah memandang perlu diadakannya penelitian terhadap persepsi siswa karena informasi dari siswa bisa dijadikan bahan masukan untuk memperbaiki sistem pembelajaran MIPA bilingual. Tanggapan siswa bisa dijadikan bahan refleksi terhadap proses belajar-mengajar. Temuan wawancara dengan kepala sekolah menunjukkan bahwa sekolah telah memberikan dukungan administratif dan manajerial yang diperlukan oleh guru. Masalahnya ialah bagaimana mengubah pola pikir yang sudah mapan dan keluar dari kebiasaan yang sudah mapan (comfort zone) untuk mendukung cita-cita RSBI yang dicanangkan oleh pemerintah.

\section{SIMPULAN DAN SARAN}

Berdasarkan uraian di atas dapat disimpulkan bahwa proses belajar-mengajar MIPA bilingual belum berjalan sesuai dengan harapan karena adanya beberapa kendala kompetensi bahasa Inggris guru dan siswa. Pola pelatihan bahasa Inggris untuk guru yang selama ini dilaksanakan tidak memenuhi kebutuhan guru MIPA karena materi yang diberikan tidak didasarkan pada needs analysis. Guru-guru bahasa Inggris di sekolah belum dilibatkan dalam suatu sistem pembelajaran MIPA bilingual. Dukungan manajerial dan administratif dari sekolah sangat $\mathrm{cu}-$ kup untuk pelaksanaan pembelajaran MIPA bilingual, tetapi tidak dimanfaatkan oleh guru secara optimal. Pergeseran kelas bilingual dari aras kelas ke aras sekolah mempunyai implikasi ketenagaan dan psikologis yang harus dicarikan jalan pemecahannya. Berdasarkan kesimpulan tersebut di atas, perlu diadakan perubahan sistem pembelajaran MIPA bilingual dari sistem mengajar mandiri oleh guru mata pelajaran ke sistem mengajar secara tim seperti yang diuraikan di bawah ini.

RSBI memerlukan pembaruan daya dukung berupa sarana dan prasarana pendidikan, sistem manajemen sekolah, dan guru yang bermutu yang dapat menguasai teknologi informasi.Sistem pembelajaran yang konvensional yang bergantung pada papan tulis dan kapur dan dibatasi oleh ruang kelas yang statis tidak dapat lagi sepenuhnya mendukung sistem pembelajaran yang dituntut oleh RSBI. Oleh sebab itu, perlu dirancang model pembelajaran yang dapat mengakomodasi cita-cita RSBI dan perkembangan teknologi agar pembelajaran dapat efektif dan kompetitif. Model tersebut dapat dilihat pada gambar 1 .

Model ini menunjukkan bahwa dalam kelas bilingual perlu ada dua orang guru, misalnya guru bahasa Inggris yang bertanggung jawab mengajarkan masalahmasalah kebahasaan (Inggris) dan guru matematika yang bertanggung jawab 


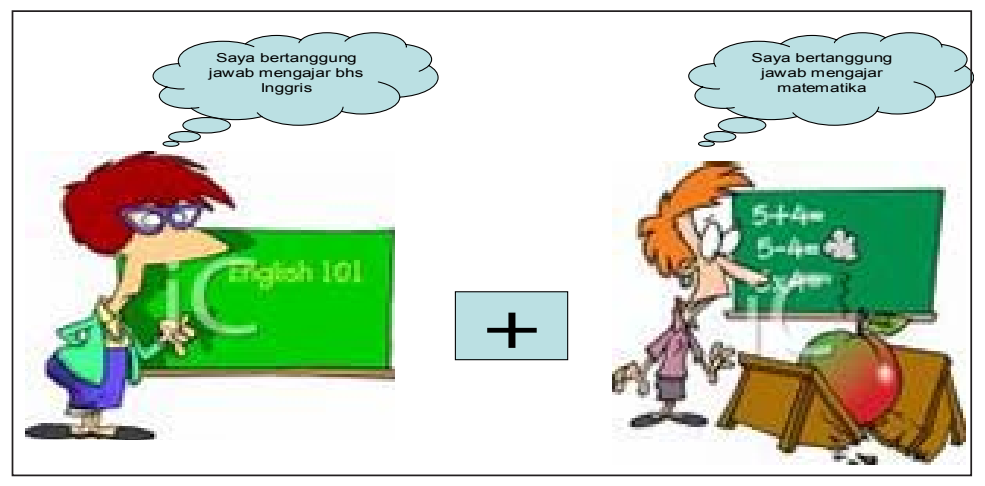

Gambar 1. Model Kelas Bilingual

mengajarkan substansi pelajaran matematika.Bahan ajar dalam model seperti ini sudah tentu harus dalam bahasa Inggris. Dalam pelaksanaan pembelajaran, konsep-konsep matematika dapat diajarkan terlebih dahulu oleh guru matematika dalam bahasa Indonesia dan beberapa kata dalam bahasa Inggris yang dikuasainya dengan baik. Sesudah itu guru bahasa Inggris mengajarkan masalah-masalah kebahasaan dalam bahasa Inggris yang diperlukan untuk memahami bahan ajar matematika dalam bahasa Inggris. Oleh karena siswa sudah diajar konsep-konsep matematika, mereka sudah mempunyai pengetahuan tentang pokok bahasan dan pengetahuan ini dapat membantu pemahaman mereka untuk mengetahui bahan tersebut dalam bahasa Inggris. Dengan model seperti ini, kelemahan guru matematika yaitu kurangnya kemampuan bahasa Inggris,dapat dibantu oleh guru bahasa Inggris dan guru bahasa Inggris tidak perlu lagi mengajarkan konsepkonsep matematika. Dalam kondisi yang ada sekarang di mana guru mata pelajaran belum sepenuhnya dapat mengajar kelas bilingual secara mandiri, pendampingan guru bahasa Inggris dengan model ini sangat diperlukan. Model ini dapat membantu siswa menguasai substansi mata pelajaran dan bahasa Inggris secara bersamaan. Keberhasilan dari model ini sudah tentu akan bergantung kepada banyak faktor. Namun demikian, perlu diperhatikan bahwa kerjasama kedua orang guru harus mulai dari pembahasan tentang KTSP, desain silabus, seleksi dan atau adaptasi materi, dan proses belajarmengajar di kelas. Dalam setiap tahap dari pengembangan model ini harus disertai dengan evaluasi dengan mempertimbangkan konteks belajar (learning needs) dan tujuan belajar (target needs) seperti yang dapat dilihat dalam bagan 1 .

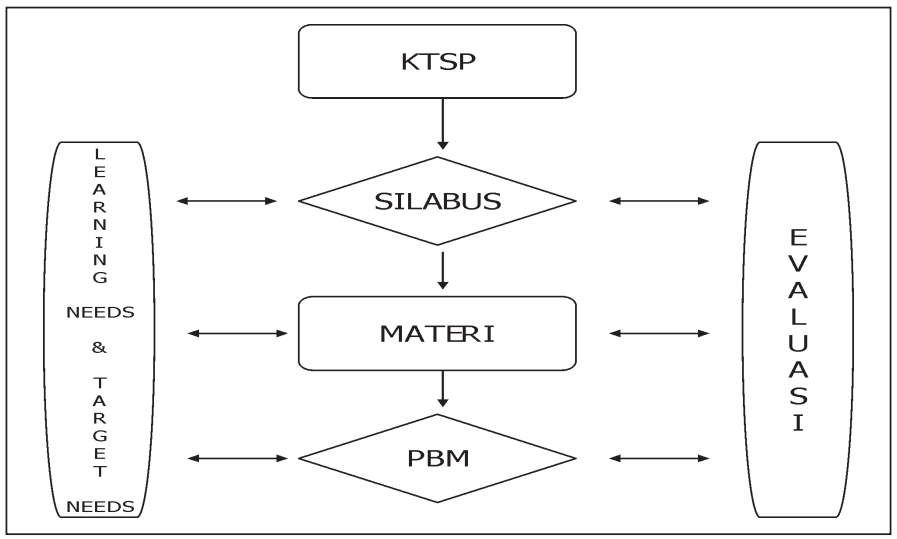

Bagan 1. Pengembangan Model Kelas Bilingual 
Model seperti ini juga disebut coteaching (Liu, 2008) yang dikembangkan di sekolah dasar di Cina dalam kelaskelas bilingual. Guru yang terlibat dalam co-teaching ialah guru penutur asli berbahasa Inggris dan guru lokal. Dalam pelaksanaan pembelajaran di kelas, mereka bekerjasama mulai dari perencanaan pelajaran sampai dengan pelaksanaan evaluasi. Model ini telah menunjukkan hasil yang menggembirakan.Di Indonesia, untuk memperoleh guru penutur asli berbahasa Inggris sangat sulit. Namun demikian, kendala ini bisa diatasi dengan melibatkan guru bahasa Inggris yang ada di sekolah dengan mempertimbangkan masalah-masalah administratif dan manajerial sekolah.

Ada beberapa hal yang perlu diperhatikan dalam pelaksanaan team teaching (Liu, 2008). Dalam team teaching, guruguru yang terlibat mempunyai tanggung jawab dan status yang sama. Secara bersama-sama mereka merancang perencanaan mengajar, mengadakan evaluasi dan bertanggung jawab kepada semua siswa di kelas. Guru bahasa Inggris dalam team teaching tidak lagi dianggap sebagai asisten guru mata pelajaran, tetapi dianggap sebagai sumber pengetahuan, fasilitator, dan guru yang mempunyai status yang sama. Dengan kata lain, kedua guru secara efektif saling melengkapi satu sama lain sesuai dengan tanggung jawabnya masing-masing dalam proses belajar-mengajar.

Model team teaching ini bisa berhasil hanya jika kedua guru memiliki keterampilan dan hubungan kerja yang kuat, profesional, mempunyai rasa saling percaya, danbersedia menyediakan waktu yang cukup untuk mewujudkan tujuan pengajaran. Guru yang terlibat dalam team teaching harus mempunyai pengalaman mengajar yang cukup. Mereka perlu memahami peran masing-masing di kelas, jika tidak, hal ini dapat mempengaruhi kenerja tim dan dapat dianggap sebagai kompetisi antara guru dalam tim, yang akhirnya dapat melemahkan semangat kerja. Team teaching harus dipahami sebagai usaha untuk meningkatkan kompetensi mengajar dan melengkapi kelemahan masing-masing sebagai guru kelas bilingual.

Strategi pelaksanaan team teaching harus juga dirancang dengan dua tahap. Tahap pertama ialah persiapan. Pada tahap ini, guru mata pelajaran dan guru bahasa Inggris membicarakan bagaimana cara mengajar siswa secara efektif. Diskusi difokuskan pertama-tama pada tingkat kemampuan siswa secara keseluruhan dalam kelas yang akan diajar, kekuatan dan kelemahan mereka, aspek apa yang perlu diperhatikan, masalah disiplin, dll. Guru dalam tim harus merumuskan tujuan pembelajaran dan menentukan topik bahasan untuk satu semester. Persiapan ini bisa memerlukan beberapa pertemuan agar setiap guru memahami apa yang menjadi sasaran pembelajaran, memahami ciri-ciri pengajaran dalam tim, dan mengembangkan rasa percaya diri.

Model pengajaran ini juga memerlukan pertemuan dan diskusi secara teratur selama semester berjalan untuk merencanakan persiapan pengajaran. Oleh sebab itu, sangat penting bagi guru untuk mengadakan pertemuan secara teratur guna merencanakan unit-unit pelajaran, antara lain menyangkut apa yang akan diajarkan, materi atau sumber belajar yang akan dipakai, peran dan tanggung jawab masing-masing guru, bagaimana mengevaluasi belajar siswa, dan bagaimana cara membantu siswa yang lemah atau yang perlu bantuan.

Masalah-masalah ini memerlukan diskusi mendalam agar peran dan tanggung jawab masing-masing guru menjadi jelas. Setiap guru harus mempunyai hak untuk mengutarakan pendapat dan memberikan kontribusi positif dalam membuat rencana pembelajaran. Pada dasarnya, setiap guru dalam tim perlu menyadari pentingnya toleransi, adanya perbedaan, dan mencari 
jalan untuk membuat perencanaan yang bermanfaat bagi siswa.

Tahap kedua ialah pelaksanaan. Dalam pelaksanaannya, model team teaching memerlukan dukungan manajerial dan administratif. Guru akan memerlukan waktu lebih banyak, program akan mempunyai dampak terhadap fasilitas mengajar, jadwal mengajar, dan dukungan finansial dalam pengadaan alat dan sumber belajar. Keberhasilan team teaching akan sangat bergantung kepada manajemen sekolah yang harus mengambil langkah-langkah sebagai berikut (Liu, 2008): menciptakan kondisi kerja yang kondusif bagi guru dalam tim untuk merencanakan pelajaran, membagi beban mengajar secara proporsional untuk guru dalam tim, bersama-sama dengan semua guru menciptakan kegiatan yang dapat membangun relasi yang harmonis dan produktif, dan membangun kesadaran yang kuat akan pentingnya kerjasama dalam menangani isu pendidikan dalam model team teaching agar terbentuk kondisi yang dapat mendukung keberhasilan program.

Tanpa dukungan yang terus-menerus dari manajemen sekolah, semangat model team teaching bisa berubah menjadi frustasi dan implementasinya akan menghasilkan pembelajaran yang tidak efektif. Menurut Elena (2006), efektivitas seseorang dapat berkembang melalui dorongan dan dukungan orang lain. Setiap orang dapat diyakinkan bahwa dia memiliki keterampilan dan kemampuan untuk menyelesaikan tugas tertentu dan mencapai keberhasilan.Dukungan dan dorongan secara verbal dapat meningkatkan usaha seseorang untuk mencapai tujuan, bukannya malahmenyerah ketika dia mengalami hambatan.

Menurut Lee (2008), dari hasil penelitiannya tentang team teaching, rahasia keberhasilan terletak pada adanya sikap terbuka dari guru dan cara menghindari konflik dalam tim. Mereka melaksana- kan perannya secara fleksibel, kadangkadang sebagai 'asisten' kadang-kadang sebagai guru utama (pemimpin) dengan tetap berpedoman pada tujuan dan arah pembelajaran. Mereka percaya bahwa setiap guru harus bersedia untuk saling mendengarkan dan menerima saran satu sama lain, mempelajari masalah yang muncul, dan mencari win-win solution. Dalam proses merencanakan kelas bilingual perlu disadari bahwa pertemuan yang teratur antara guru bahasa Inggris dan guru mata pelajaran mutlak harus dilaksanakan karena mereka harus membangun komitmen yang berkelanjutan dan menyediakan waktu untuk merencanakan kelas bilingual.

\section{UCAPAN TERIMAKASIH}

Kami mengucapkan banyak terima kasih kepada DP2 M Dikti yang telah mendanai penelitian ini pada tahun anggaran 2010. Ucapan terima kasih juga kami sampaikan kepada sekolah-sekolah sampel di Jawa Tengah dan para guru yang telah memberi izin pelaksanaan penelitian ini. Demikian juga kepada Universitas Kristen Satya Wacana, atas dukungan yang diberikan sehingga penelitian ini dapat diselesaikan.

\section{DAFTAR PUSTAKA}

Astika, G. 2007.Readings in Language Teaching and Research. Salatiga: Widya Sari Press.

Astika, G., Wahyana, A., Andreyana, R. 2008. Kemampuan bahasa Inggris guru SMA Negeri 1 dan SMK Negeri 2 Salatiga dalam mendukung program SBI. Laporan Penelitian Fakultas Bahasa dan Sastra, Universitas Kristen Satya Wacana, Salatiga.

Brinton, D. M., Snow, M. A., \& Wesche, M. B. 1989. Content-Based Second Language Instruction. Boston: Heinle \& Heinle.

Dudley-Evans, T., \& St John, M. J. 1998.Developments in ESP: A multi-disciplinary approach. New York: Cambridge University Press. 
Doughty, C. \& William, J. 1998. Pedagogical choices in focus on form. In C. Doughty and J. Williams (Eds.) Focus on Form in Classroom Second Language Acquisition (pp.197-261). New York: Cambridge University Press.

Elena, S. L. 2006. Recruiting Paraeducators Into Bilingual Teaching Roles: The Importance of Support, Supervision, and Self-Efficacy. Bilingual Research Journal.

Gillett, A. 2007.Using English for Academic Purposes. Http://www. UEfAP, Speaking in Academic Contexts, html. Accessed: May 9, 2008.

Hutchinson, T. \& Waters, A. 2006.English for Specific Purposes. Cambridge: Cambridge University Press.

Liu, L. 2008. Co-teaching between native and non-native English teachers: An exploration of co-teaching models and strategies in the Chinese primary school context. Reflections on English language teaching, vol 7 (2), 103-117.

Lee, C. 2008. Interdisciplinary collaboration in English language teaching: Some observations from subject teachers' reflections. Reflections on English Language Teaching, vol 7, (2), 129-138).
Nunan, D. 1995.Research Methods in Language Teaching. Cambridge: Cambridge University Press.

Peraturan Pemerintah Nomor 19 Tahun 2005 tentang Standar Nasional Pendidikan.

Permendiknas Nomor 23 Tahun 2006 tentang Standar Kompetensi Lulusan.

Rice, P.L. \& Ezzy, D. 1999. Qualitative Research Methods. Oxford: Oxford University Press.

Seliger, H.W. \& Shohamy, E. 1989. Second Language Research Methods. Oxford: Oxford University Press.

Undang-Undang Nomor 20 Tahun 2003 tentang Sistem Pendidikan Nasional.

Weisberg, R. 2006. Scaffolded feedback: Tutorial conversations with advanced L2 writers. In K. Hyland \& F. Hyland (Eds.).Feedback in Second Language Writing (pp. 246-265). Cambridge: Cambridge University Press.

Yule, G. 1997.Referential Communication Tasks. Mahwah: Lawrence Erlbaum Associates. 